\title{
Two interesting records of millipedes (Diplopoda) from near Borjomi, Georgia
}

\section{Аве интересные находки двупарноногих многоножек (Diplopoda) бциз Боржоми (Грузия)}

\author{
Mzia S. Kokhia ${ }^{1}$, Aleksandr P. Evsyukov' ${ }^{2}$, Sergei I. Golovatch ${ }^{3}$ \\ Мзия С. Кохия ${ }^{1}$ Александр П. Евсюков ${ }^{2}$, Сергей И. Головач ${ }^{3}$
}

\footnotetext{
${ }^{1}$ Institute of Zoology, Ilia State University, Tbilisi, Georgia. E-mail: mzia.kokhia@iliauni.edu.ge

${ }^{1}$ Институт зоологии, Государственный университет им. Илии, Тбилиси, Грузия.

2 Don State Technical University, Department of Biology and General Pathology, Gagarin Square 1, Rostov-on-Don 344003, Russia. Email: aevsukov@mail.ru

2 Донской государственный технический университет, кафедра биологии и общей патологии, пл. Гагарина 1 , Ростов-на-Дону 344003, Россия.

${ }^{3}$ Institute for Problems of Ecology and Evolution, Russian Academy of Sciences, Leninsky pr. 33, Moscow 119071, Russia. E-mail: sgolovatch@yandex.ru.

${ }^{3}$ Институт проблем экологии и эволюции РАН, Ленинский проспект 33, Москва 119071, Россия.
}

KEY WORDS: Polydesmida, Polydesmus abchasius, Julida, Julus lindholmi, new records.

КЛЮЧЕВЫЕ СЛОВА: Polydesmida, Polydesmus abchasius, Julida, Julus lindholmi, новые находки.

ABSTRACT. Polydesmus abchasius Attems, 1898 and Julus lindholmi Lohmander, 1936, both found recently near Borjomi, central Georgia, currently represent the southeasternmost records of the genera Polydesmus Latreille, 1803, subgenus Polydesmus s.str., and Julus Linnaeus, 1758, and of both these widespread, endemic, Caucasian millipede species.

PЕЗЮМЕ. Polydesmus abchasius Attems, 1898 и Julus lindholmi Lohmander, 1936, недавно найденные близ Боржоми (Центральная Грузия), пока представляют собой самые юго-восточные находки как родов Polydesmus Latreille, 1803, подрод Polydesmus s.str., и Julus Linnaeus, 1758, так и этих широкораспространенных эндемичных кавказских видов диплопод.

\section{Introduction}

The millipede fauna of Georgia, Caucasus is known to be remarkably rich and diverse in the entire Caucasian region, presently amounting to 103 species from 44 genera, 12 families, and seven orders [Kokhia, Golovatch, 2020]. Most of the Diplopoda known from Georgia ( 86 species, or $83 \%$ ) demonstrate Caucasian distribution patterns, 36 and 46 species, as well as eight and nine genera being endemic or subendemic to the country, respectively.

Prompted by the recent discovery by one of us (MSK) of two interesting millipede species near Bor- jomi, central Georgia, we put them on record below, because both currently represent the southeasternmost range limits of the genera Polydesmus Latreille, 1803 and Julus Linnaeus, 1758, and of Polydesmus abchasius Attems, 1898 and Julus lindholmi Lohmander, 1936, both widespread, endemic, Caucasian millipedes.

The new samples have been deposited in the collection of the Zoological Museum, Moscow State University (ZMUM), Russia.

Taxonomic part

Polydesmus abchasius Attems, 1898

MATERIAL. 1 \& (ZMUM), Georgia, Borjomi, National Park, in litter, 30.X.2019, M.S. Kokhia leg.

REMARKS. The whole family Polydesmidae, including this easily recognizable species (usually intense red, with particularly broad and upturned paraterga), has recently been reviewed in the scope of the entire Caucasian fauna [Golovatch et al., 2016]. The species has hitherto been recorded only from the western Caucasus within the Krasnodar Province, Abkhazia and western Georgia. Above is thus the first report of $P$. abchasius from central Georgia, apparently the species' southeasternmost range limit. The same concerns Polydesmus s.str., a group of only rather few Euro-Mediterranean species.

Julus lindholmi Lohmander, 1936

MATERIAL. $3 O^{\top} \sigma^{\top}, 6$ + 9 (ZMUM), Georgia, Borjomi, National Park, in litter, 30.X.2019, M.S. Kokhia leg.

REMARKS. The whole genus Julus Linnaeus, 1758, including $J$. lindholmi, has recently been reviewed in the

How to cite this article: Kokhia M.S., Evsyukov A.P., Golovatch S.I. 2020. Two interesting records of millipedes (Diplopoda) from near Borjomi, Georgia // Russian Entomol. J. Vol.29. No.1. P.121-122. doi: 10.15298/rusentj.29.1.16 
scope of the entire Caucasian fauna [Evsyukov et al., 2018] The species has hitherto been recorded only from the northwestern Caucasus within the Stavropol Province, Karachaevo-Cherkessia (both Russia), Abkhazia and Svanetia (Georgia). Above is thus the first report of J. lindholmi from central Georgia, apparently the species' southeasternmost range limit as well.

Acknowledgement. The last author was supported by the Presidium of the Russian Academy of Sciences, Program No. 41 "Biodiversity of natural systems and biological resources of Russia". The first author was supported by the project "Fauna of Georgia - Current Trends and Conservation", with special thanks to Dr. O. Gorgadze for the help in collecting the material.

\section{References}

Evsyukov A.P., Golovatch S.I., Reip H.S. 2018. The millipede genus Julus Linnaeus, 1758 in the Caucasus (Diplopoda: Julida: Julidae) // Zootaxa. Vol.4461. No.1. P.89-117.

Golovatch S.I., Evsyukov A.P., Reip H. 2016. The millipede family Polydesmidae in the Caucasus (Diplopoda: Polydesmida) // Zootaxa. Vol.4085. No.1. P.1-51.

Kokhia M.S., Golovatch S.I. 2020. Diversity and distribution of the millipedes of Georgia, Caucasus (Diplopoda) // ZooKeys. [in press]. 